\title{
KARAKTERISTIK MOLEKULER KELELAWAR (MICROCHIROPTERA), BERDASARKAN DNA MITOKONDRIA (GEN COI) DI GUA SUKABUMI DAN SENTUL JAWA BARAT
}

\section{MOLECULAR CHARACTERISTICS OF BATS (MICROCHIROPTERA) BASED ON MITOCHONDRIAL DNA: COI IN THE CAVE SUKABUMI AND SENTUL}

\author{
Ismayati Afifah $^{1 *}$, Dedy Duryadi Solihin ${ }^{1}$, Arzyana Sunkar ${ }^{2}$ \\ ${ }^{1}$ Program Studi Biosains Hewan, Fakultas Matematika dan Ilmu Pengetahuan Alam, Institut Pertanian Bogor \\ ${ }^{2}$ Departemen Konservasi Sumberdaya Hutan dan Ekowisata, Fakultas Kehutanan, Institut Pertanian Bogor \\ *Corresponding author: dduryadi@yahoo.com
}

Naskah Diterima: 11 Januari 2020; Direvisi: 10 April 2020; Disetujui: 4 Oktober 2021

\begin{abstract}
Abstrak
Cytochrome Oxidase I (COI) merupakan salah satu gen mitokondria untuk membantu konstruksi dari pohon filogeni yang dapat bertindak sebagai gen marker. Gen COI memiliki keakuratan dalam mengidentifikasi spesies dan umumnya digunakan sebagai "DNA Barcoding". Informasi mengenai karakteristik genetik berdasarkan DNA mitokondria pada kelelawar di Sukabumi dan Sentul belum banyak dilaporkan. Tujuan dari penelitian ini untuk mengetahui keragaman genetik kelelawar berdasarkan DNA mitokondria dengan penanda Cytochrome Oxidase I (COI) sebagai DNA barcoding. Isolasi DNA total dilakukan menggunakan Kit Dneasy ${ }^{\circledR}$ Blood and Tissue Kit cat no 69504 (50) berdasarkan prosedur Spin-Column Protocol dengan modifikasi. Hasil penelitian ini menunjukkan bahwa gen COI telah berhasil mengidentifikasi karakteristik spesies. Dua haplotipe didapatkan dari masing-masing populasi. Berdasarkan barcode DNA menunjukkan populasi Sukabumi merupakan spesies Chaerephon plicatus dengan nilai identitas genetik sebesar 97,08\%, sedangkan populasi Sentul menunjukkan perbedaan secara genetik dengan spesies Hipposideros larvatus dengan nilai identitas genetik sebesar 94,85\%. Identifikasi secara genetik dengan menggunakan gen COI menunjukkan bahwa kelelawar yang berasal Sukabumi adalah spesies Chaerephon plicatus dengan jarak genetik sebesar 3,1\%. Kelelawar yang berasal dari Sentul memiliki kedekatan dengan spesies Hipposideros larvatus namun memiliki jarak genetik sebesar $5,2 \%$.
\end{abstract}

Kata kunci: COI; Gua; Identifikasi spesies; Kelelawar; Sentul; Sukabumi

\begin{abstract}
Cytochrome Oxidase I (COI) is one of the mitochondrial genes to help the construction of phylogeny trees that can act as marker genes. The COI gene has accuracy in identifying species and is commonly used as "DNA Barcoding". Information about genetic characteristics based on mitochondrial DNA in bats in Sukabumi and Sentul has not been widely reported. The purpose of this study was to determine the genetic diversity of bats based on Mitochondrial DNA with Cytochrome Oxidase I (COI) markers as DNA barcoding. Total DNA isolation was carried out using the Dneasy ${ }^{\circledR}$ Blood and Tissue Kit paint no. 69504 (50) based on the Spin-Column Protocol procedure with modifications. The results of this study indicate that the COI gene has successfully identified species characteristics. Two haplotypes were obtained from each population. Based on DNA barcodes, the population of Sukabumi is a species of Chaerephon plicatus with a genetic identity value of $97.08 \%$, while the Sentul population shows genetic differences with the Hipposideros larvatus species with a genetic identity value of $94.85 \%$. Genetic identification using the COI gene shows that the bats originating from Sukabumi is a spesies Chaerephon plicatus with a genetic distance of $3.1 \%$. The bats originating from Sentul are closely related to the species Hipposideros larvatus but have a genetic distance of $5.2 \%$.
\end{abstract}

Keywords: Bats; Cave; COI; Sentul; Species identification; Sukabumi

Permalink/DOI: http://dx.doi.org/10.15408/kauniyah.v14i1.14147 


\section{PENDAHULUAN}

Kelelawar merupakan mamalia yang memiliki kemampuan terbang. Kelelawar diklasifikasikan ke dalam ordo Chiroptera. Ordo tersebut dibagi menjadi dua subordo, yaitu Megachiroptera (pemakan buah-buahan) dan Microchiroptera (pemakan serangga) (Suyanto, 2001). Kelelawar berperan penting dalam proses ekologi, seperti membantu penyebaran benih, penyerbukan, dan penyeimbang populasi serangga (Aguirre, Lens, \& Matthysen, 2003). Keberadaan kelelawar di dalam gua, dapat berperan sebagai kunci penyedia energi ekosistem (key factor in cycle energy) bagi organisme yang ada di dalam gua. Oleh sebab itu, apabila ekosistem gua tidak dikelola dengan baik, dapat mengganggu keseimbangan ekosistem, baik ekosistem yang ada di dalam gua maupun ekosistem yang ada di luar gua (Wijayanti, 2011).

Spesies kelelawar yang sama ditemukan dalam satu gua dapat disebabkan oleh beberapa faktor, beberapa faktor tersebut di antaranya ialah kondisi lingkungan yang sesuai, makanan yang masih tersedia, dan ketidakhadiran predator, sehingga masih banyak kelelawar yang hidup, dan bertahan di tempat tersebut. Kondisi mikroklimat yang sesuai dengan kebutuhan kelelawar. Seckerdieck, Walther, dan Halle (2005) membuktikan bahwa kelelawar mempunyai home instink yang kuat, tempat tinggal yang dipilih kelelawar dipertahankan sampai beberapa generasi. Apabila tempat tinggal mendapat ganggguan dan kelelawar tidak nyaman dan aman, tempat tinggal ini akan ditinggalkan (Willis \& Brigham, 2004).

International Union for Conservation of Nature (IUCN) menyatakan bahwa kawasan karst memegang peranan penting bagi kelangsungan biodiversitas di bumi. Hal ini karena kawasan karst memiliki keunikan biodiversitas, baik di permukaan (eksokarst) maupun di bawah permukaan (endokarst). Kelelawar adalah salah satu biodiversitas di endokarst. Di dunia terdapat 18 famili, 192 genus, dan lebih dari 977 spesies kelelawar (Nowak, 1999). Di Indonesia, terdapat 8 famili, di dalamnya terdapat 72 spesies anggota subordo Megachiroptera dan 133 spesies anggota subordo Microchiroptera yang sebagian besar hidup di gua. Namun, seluruh biodiversitas termasuk kelelawar khususnya anggota subordo Microchiroptera yang memiliki peranan penting secara ekologi dan bagi masyarakat di kawasan karst mengalami ancaman kepunahan massal.

Genetika molekuler dibutuhkan terkait dengan ketepatan mengidentifikasi spesies dan mendukung hasil identifikasi berdasarkan sifat morfologi. Identifikasi suatu organisme mulai spesies hingga subspesies secara akurat terhadap berbagai spesies yang sulit dibedakan secara morfologi dapat menggunakan DNA barcoding (Hebert, Ratnasingham, \& De Waard, 2003). Gen Cytochrome Oxydase I (COI) merupakan salah satu kelompok gen yang dapat dijadikan sebagai marka molekuler untuk penentuan spesies pada DNA mitokondria (Solihin, 1994).

Gua di kawasan Sukabumi dan Sentul Jawa Barat merupakan tempat tinggal bagi komunitas kelelawar. Gua di kawasan ini dijadikan sebagai objek wisata, sehingga dikhawatirkan populasi kelelawar di dalamnya maupun ekosistem gua itu sendiri akan mengalami gangguan. Ekosistem terutama dalam kaitannya dengan ekosistem luar gua, maka dibutuhkan pola pengelolaan gua yang tepat. Pola pengelolaan gua yang tepat dan sesuai dengan tujuan yang diharapkan, diperlukan informasi yang luas mengenai ekosistem gua serta segala sesuatu yang menyangkut berlangsungnya proses ekologi yang terkait.

Tujuan penelitian ini adalah untuk mengkaji keragaman genetik kelelawar berdasarkan DNA mitokondria dengan penanda COI sebagai DNA barcoding. Hasil penelitian ini diharapkan dapat memberikan informasi mengenai keragaman kelelawar dan memberikan informasi tentang identitas molekuler kelelawar melalui pendekatan genetik berdasarkan penanda gen COI.

\section{MATERIAL DAN METODE}

Penelitian ini dilaksanakan pada April 2018. Lokasi pengambilan sampel di gua wilayah Sukabumi (Gua Lalay Palabuhan Ratu) dan Sentul (Gua Agung Garunggang). Analisis molekuler sampel kelelawar dilakukan di Laboratorium Biologi Konservasi Hewan, Pusat Penelitian Sumberdaya Hayati dan 
Bioteknologi (PPSHB) Institut Pertanian Bogor.

Identifikasi kelelawar diawali dengan penangkapan kelelawar dengan menggunakan jaring kabut (mistnet). Jaring kabut yang dipakai untuk menangkap kelelawar adalah jaring yang memiliki mesh (lebar mata jaring) 30-32 mm dengan ketebalan benang jaring 80 Denier $(1$ Denier $=$ masa $90 \mathrm{~m}$ benang nilon skala gram). Penangkapan kelelawar juga dapat menggunakan handnet, terutama untuk kelelawar yang berukuran besar. Kelelawar yang diidentifikasi ialah kelelawar yang sudah dewasa dan utuh tubuhnya (Suyanto, 2001).

\section{Isolasi DNA Total}

DNA diekstraksi dari darah kelelawar. Isolasi DNA total dilakukan menggunakan Kit Dneasy® Blood and Tissue Kit cat no 69504 (50) berdasarkan prosedur Spin-Column Protocol (Qiagen, 2003). Darah dimasukkan ke dalam tube sebanyak $40 \mu \mathrm{L}$, ditambahkan larutan ATL sebanyak $200 \mu \mathrm{L}$, ditambahkan Proteinase-K sebanyak $25 \mu \mathrm{L}$, diinkubasi pada suhu $56{ }^{\circ} \mathrm{C}$ selama 1 jam, ditambahkan larutan AL sebanyak $200 \mu \mathrm{L}$, dihomogenkan secara manual menggunakan tangan, diinkubasi pada suhu $56{ }^{\circ} \mathrm{C}$ selama 10 menit, ditambahkan EtOH sebanyak $200 \mu \mathrm{L}$, simpan di dalam freezer selama 1 jam, dihomogenkan kembali secara manual menggunakan tangan. Sampel dipindahkan ke dalam spin colomn, dihomogenkan menggunakan sentrifus dengan kecepatan 8.000 rpm selama 1 menit, ditambahkan larutan AW 1 sebanyak $500 \mu \mathrm{L}$, dihomogenkan menggunakan sentrifus dengan kecepatan 8.000 rpm selama 1 menit, ditambahkan larutan AW 2 sebanyak $500 \mu \mathrm{L}$, dihomogenkan menggunakan sentrifus dengan kecepatan $13.000 \mathrm{rpm}$ selama 1 menit, cairan dibuang, kemudian dihomogenkan kembali menggunakan sentrifus dengan kecepatan $13.000 \mathrm{rpm}$ selama 1 menit, ditambahkan larutan $\mathrm{AE}$ sebanyak $100 \mu \mathrm{L}$ dan diamkan selama 15 menit. Sebanyak 2-3 $\mu$ L larutan ini digunakan sebagai template campuran Polymerase Chain Reaction (PCR).

\section{Amplifikasi Gen COI DNA Mitokondria dan Sekuensing Produk PCR}

Proses replikasi DNA melalui PCR dengan menggunakan bahan kit PCR dan
dNTP. Volume komposisi bahan-bahan PCR sebanyak $25 \mu \mathrm{L}$ yang terdiri atas $\mathrm{ddH}_{2} \mathrm{O} ; 8,8$ $\mu \mathrm{L}$. 5x Buffer Q5; 4,0 $\mu \mathrm{L}, 5 \mathrm{x}$ Enhancer Q5; 5,0 $\mu \mathrm{L}, \quad \mathrm{dNTP} ; \quad 1,0 \mu \mathrm{L}$, primer forward Mc_COI_GH_F (5'-GGC GCT TGA GCA GGC ATA GT-3') dan primer reverse Mc_COI_GH_R (5'-GGG ATG CCC GAA GAA TCA GA-3'); $1,0 \mu \mathrm{L}$. DNA total; $3,0 \mu \mathrm{L}$ dan Taq DNA polymerase; 0,2 $\mu \mathrm{L}$. PCR dilakukan dengan menggunakan mesin PCR. Kondisi PCR meliputi tahapan pre-denaturasi $94{ }^{\circ} \mathrm{C}$ selama 1 menit, denaturasi $94{ }^{\circ} \mathrm{C}$ selama 45 detik, annealling $56,6{ }^{\circ} \mathrm{C}$ selama 45 detik, elongasi $72{ }^{\circ} \mathrm{C}$ selama 1 menit sebanyak 35 siklus; post PCR: ekstensi $72{ }^{\circ} \mathrm{C}$ selama 5 menit.

Sekuensing produk PCR dikerjakan di Laboratorium First Base, Selangor, Malaysia. Sampel sekuensing dikirim melalui Laboratorium Genetica Science.

\section{Analisis Data}

Data hasil sekuensing baik forward maupun reverse disejajarkan (alignment) menggunakan software Molecular Evolutionary Genetics Analysis (MEGA) versi 7,0 (Kumar, Stecher, \& Tamura, 2016). Hasil gabungan penjajaran kemudian dikoreksi dengan primer forward maupun primer reverse. Sekuen utuh hasil koreksi tersebut disejajarkan kembali antar individu dalam lokasi gua yang sama dan antar lokasi gua yang berbeda. Verifikasi hasil sekuen untuk mengetahui identitas jenis masing-masing individu berasal dari gua yang sama maupun berbeda dilakukan dengan sekuen standar dari GenBank melalui program Basic Local Alignment Search Tool-nucleotide (BLASTn) di situs National Center for Biotechnology Information (NCBI). Rekonstruksi pohon filogenetik menggunakan metode Neighborjoining dengan Bootstap 1.000x (Kumar et al., 2016).

\section{HASIL}

\section{Ekstraksi DNA dan Amplifikasi Gen COI Mitokondria}

Hasil ekstraksi DNA total, dari 11 sampel Sukabumi dan 12 sampel Sentul setelah dilakukan elektroforesis menunjukkan pita jelas dan terang (Gambar 1). Kemudian untuk mengetahui konsentrasi dari DNA dilakukan 
uji Nanodrop. Hasil uji Nanodrop kemudian dijadikan cetakan DNA untuk menunjukkan konsentrasi DNA cukup baik, mengamplifikasi gen COI dengan setelah dilakukan uji Nanodrop DNA tersebut menggunakan teknik PCR.

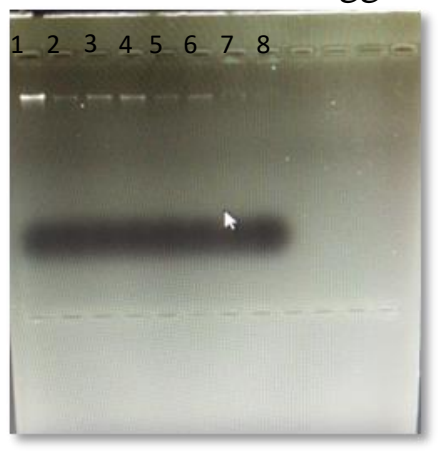

Gambar 1. Hasil pita elektroforesis DNA sampel

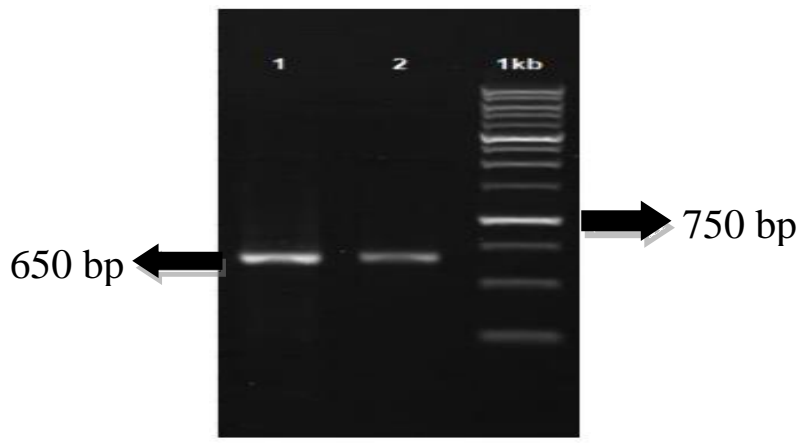

Gambar 2. Visualisasi pita DNA gen COI Sukabumi (1), Sentul (2), dan Marker 1 kb (M)

\section{Amplifikasi dan Visualisasi DNA}

Terdapat 23 sampel individu dari masingmasing lokasi, 11 individu berasal dari Gua Lalay Sukabumi dan 12 individu berasal dari Gua Agung Garunggang Sentul. Amplifikasi gen COI menggunakan primer spesifik dengan panjang sekuen 650 bp. Hasil ekstraksi DNA total, setelah dilakukan elektroforesis menunjukkan pita jelas dan terang. Hal ini karena konsentrasi DNA yang cukup tinggi (Gambar 2).

\section{Karakteristik Gen COI}

Analisis molekuler berhasil dilakukan terhadap 23 sampel terdiri atas 11 individu berasal dari Sukabumi dan 12 individu berasal dari Sentul. Amplifikasi gen COI dengan menggunakan primer spesifik menunjukkan panjang sekuen gen COI (650 bp) sesuai target (Gambar 2).

Hasil penjajaran berganda (multiple alignment) dari interpopulasi Sukabumi dan Sentul beserta outgrup Rhinolophus macrotis dan Rhinolophus luctus dari GenBank menunjukkan bahwa gen COI menghasilkan situs konservatif sebesar 467 bp $(71,08 \%)$, situs variabel 190 bp $(28,91 \%)$, situs parsimoni 139 bp (21,15\%), dan singleton 51 bp (7,7\%). Komposisi basa nukleotida gen COI interspesies menunjukkan bahwa rata-rata tertinggi adalah Timin (29,2\%), dan Sitosin $(27,7 \%)$, diikuti Adenin $(26,0 \%)$, dan paling rendah adalah Guanin $(17,0 \%)$.

\section{Identifikasi Berdasarkan Sekuen Parsial Gen COI}

Berdasarkan hasil identifikasi genetik dari masing-masing lokasi terdapat spesies Chaerephon plicatus (Sukabumi) dan Hipposideros larvatus (Sentul). Identifikasi spesies kelelawar dilakukan dengan melihat tingkat kemiripan (\%) sekuen gen COI antara spesies yang didapat dan spesies kelelawar yang tersedia di GenBank. Sampel yang berasal dari Sukabumi merupakan spesies Chaerephon plicata dengan nilai Query-cover sebesar 98\% dan nilai identity 97,08\%. Sampel yang berasal dari Sentul berdasarkan hasil BLASTn lebih dekat dengan Hipposideros larvatus dengan nilai Query-cover sebesar 97\% dan nilai identity 94,85\% (Tabel 1). 
Tabel 1. Hasil BLASTn gen COI

\begin{tabular}{|c|c|c|c|c|c|c|}
\hline \multirow[t]{2}{*}{ Lokasi } & \multirow{2}{*}{$\begin{array}{l}\text { Kode } \\
\text { sampel }\end{array}$} & \multirow[t]{2}{*}{ Spesies } & \multicolumn{4}{|c|}{ Alignment BLAST-n gen COI } \\
\hline & & & $\begin{array}{l}\text { Query- } \\
\text { cover }\end{array}$ & $\begin{array}{c}\text { Ident } \\
(\%)\end{array}$ & Kode akses & Deskripsi \\
\hline $\begin{array}{l}\text { Gua Lalay } \\
\text { Sukabumi }\end{array}$ & $\begin{array}{l}\text { SKB Sp1 } \\
\text { SKB Sp } 2 \\
\text { SKB Sp } 3 \\
\text { SKB Sp } 4 \\
\text { SKB Sp } 5 \\
\text { SKB Sp } 6 \\
\text { SKB Sp } 7 \\
\text { SKB Sp } 8 \\
\text { SKB Sp } 9 \\
\text { SKB Sp } 10 \\
\text { SKB Sp } 11\end{array}$ & $\begin{array}{l}\text { Chaerephon } \\
\text { plicatus }\end{array}$ & $98 \%$ & $97,08 \%$ & KY581660.1 & $\begin{array}{l}\text { Chaerephon plicatus } \\
\text { voucher ROM MAM } \\
118373 \\
\text { mitochondrion, partial } \\
\text { genome }\end{array}$ \\
\hline $\begin{array}{l}\text { Gua } \\
\text { Agung } \\
\text { Garungga } \\
\text { ng Sentul }\end{array}$ & $\begin{array}{l}\text { STL Sp } 1 \\
\text { STL Sp } 2 \\
\text { STL Sp } 3 \\
\text { STL Sp } 4 \\
\text { STL Sp } 5 \\
\text { STL Sp } 6 \\
\text { STL Sp } 7 \\
\text { STL Sp } 8 \\
\text { STL Sp } 9 \\
\text { STL Sp } 10 \\
\text { STL Sp } 11 \\
\text { STL Sp12 }\end{array}$ & $\begin{array}{l}\text { Hipposideros } \\
\text { larvatus }\end{array}$ & $97 \%$ & $94,85 \%$ & HM540393.1 & $\begin{array}{l}\text { Hipposideros cf. } \\
\text { larvatus CMF-2010 } \\
\text { voucher THK } 41323 \\
\text { cytochrome oxidase } \\
\text { subunit } 1 \text { (COI) gene, } \\
\text { partial cds; } \\
\text { mitochondrial }\end{array}$ \\
\hline
\end{tabular}

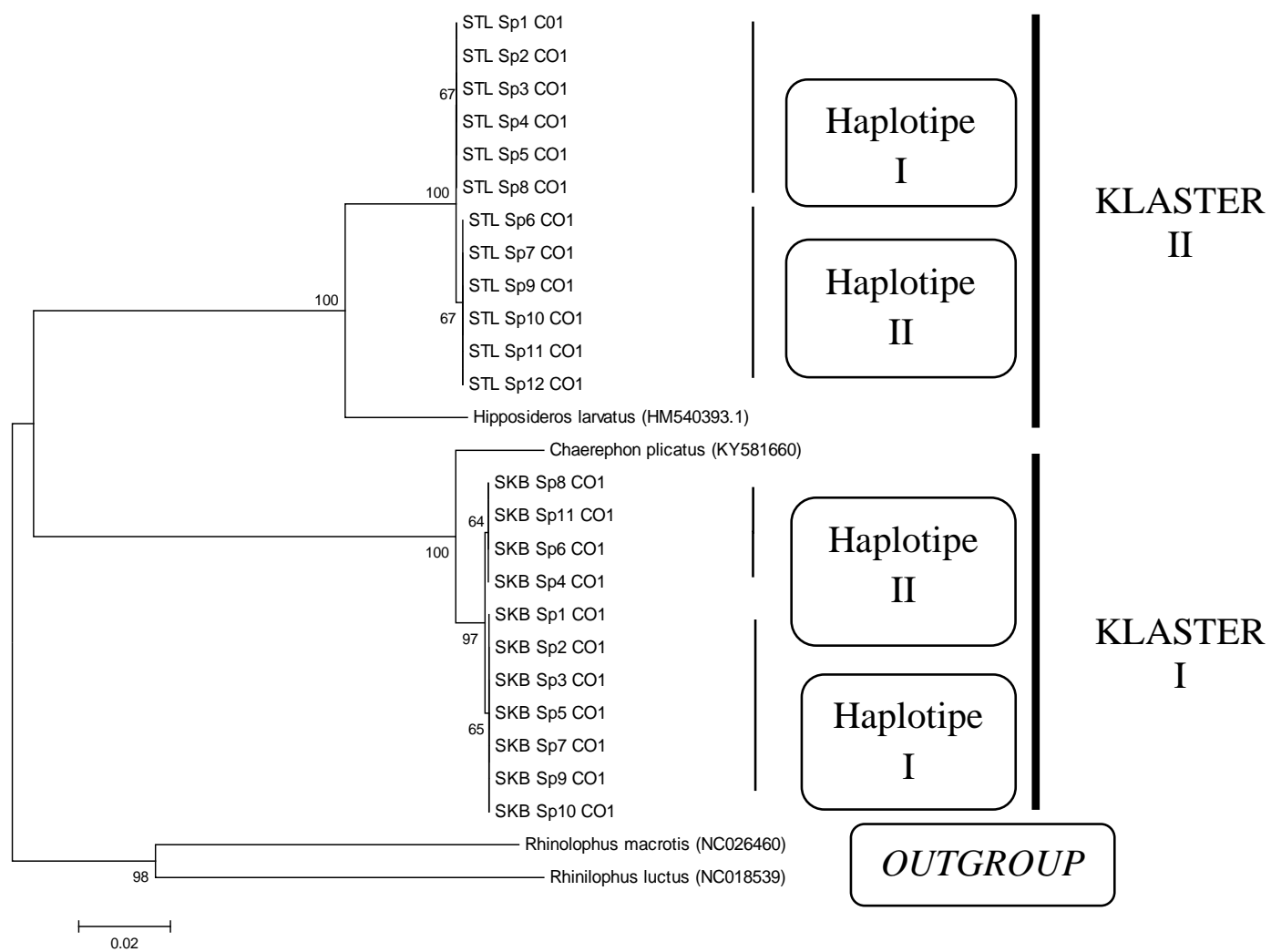

Gambar 3. Hubungan kekerabatan kelelawar asal Sukabumi dan Sentul berdasarkan bootstrap neighboor-joining (NJ) dengan 1.000 kali pengulangan dengan model evolusi kimura 2-parameter berdasarkan gen $\mathrm{COI}$ 
Tabel 2. Posisi basa nukleotida yang polimorfik berdasarkan lokasi Sukabumi dan Sentul

\begin{tabular}{|c|c|c|c|}
\hline $\begin{array}{c}\text { Populasi } \\
\text { (Sukabumi) }\end{array}$ & $\begin{array}{c}\text { Situs nukleotida } \\
\text { ke- }\end{array}$ & $\begin{array}{l}\text { Populasi } \\
(\text { Sentul) }\end{array}$ & Situs nukleotida ke- \\
\hline & 267 & & 471 \\
\hline $\begin{array}{l}\text { Chaerephon } \\
\text { plicatus } \\
\text { (KY581660) }\end{array}$ & A & $\begin{array}{l}\text { Hipposideros larvatus } \\
\text { (HM 540393.1) }\end{array}$ & $\mathrm{C}$ \\
\hline SKB Sp 1 & G & STL Sp 1 & $\mathrm{C}$ \\
\hline SKB Sp 2 & $\mathrm{G}$ & STL Sp 2 & $\mathrm{C}$ \\
\hline SKB Sp 3 & $\mathrm{G}$ & STL Sp 3 & $\mathrm{C}$ \\
\hline SKB Sp 4 & A & STL Sp 4 & $\mathrm{C}$ \\
\hline SKB Sp 5 & $\mathrm{G}$ & STL Sp 5 & $\mathrm{C}$ \\
\hline SKB Sp 6 & A & STL Sp 6 & $\mathrm{~T}$ \\
\hline SKB Sp 7 & $\mathrm{G}$ & STL Sp 7 & $\mathrm{~T}$ \\
\hline SKB Sp 8 & A & STL Sp 8 & $\mathrm{C}$ \\
\hline SKB Sp 9 & $\mathrm{G}$ & STL Sp 9 & $\mathrm{~T}$ \\
\hline SKB Sp 10 & $\mathrm{G}$ & STL Sp 10 & $\mathrm{~T}$ \\
\hline SKB Sp 11 & $\mathrm{~A}$ & STL Sp 11 & $\mathrm{~T}$ \\
\hline & & STL Sp 12 & $\mathrm{~T}$ \\
\hline
\end{tabular}

Tabel 3. Jarak genetik intra dan inter populasi kelelawar asal Sukabumi dan Sentul berdasarkan gen COI

\begin{tabular}{ll}
\hline \multicolumn{1}{c}{ Lokasi } & \multicolumn{1}{c}{ Jarak genetik } \\
\hline Sukabumi & $0,001(0,1 \%)$ \\
Sentul & $0,001(0,1 \%)$ \\
Sukabumi vs Sentul & $0,192(19,2 \%)$ \\
Sukabumi vs Chaerephon plicatus (KY581660) & $0,031(3,1 \%)$ \\
Sentul vs Hipposideros larvatus (HM 540393.1) & $0,052(5,2 \%)$ \\
\hline
\end{tabular}

\section{Hubungan Kekerabatan dan Keragaman Haplotipe Intraspesies}

Rekonstruksi pohon filogenetik pada Rekonstruksi pohon filogenetik pada sampel kelelawar asal Sukabumi dan Sentul dilakukan berdasarkan model kimura 2-parameter dan metode Neighbor-Joining (NJ) dengan nilai Bootstrap 1.000 kali pengulangan. Hasil rekonstruksi pohon filogenetik pada sampel Sukabumi, Sentul dan outgroup menunjukkan dua klaster. Klaster (I) terdiri atas populasi Sukabumi (1a) dan spesies Chaerephon plicatus (KY581660.1) (1b), klaster (II) terdiri atas populasi Sentul (2a) dan spesies Hipposideros larvatus (HM540393.1) (2b), sedangkan Outgroup terdiri atas Rhinolophus macrotis dan Rhinolophus luctus (Gambar 3).

Hasil analisis haplotipe intraspesies pada populasi Sukabumi dan Sentul menunjukkan masing-masing dua haplotipe berbeda. Klaster (I) berdasarkan gen COI menunjukkan bahwa terdapat subklaster dari populasi Sukabumi (Ia) yang terdiri atas dua haplotipe: haplotipe satu terdiri atas individu $1,2,3,5,7,9$, dan 10 . Haplotipe dua terdiri atas individu 4, 6, 8, dan 11. Klaster (II) terdapat subklaster dari populasi Sentul (2a) yang terdiri atas dua haplotipe: haplotipe satu terdiri atas individu 1 , 2, 3, 4, 5, dan 8 serta haplotipe dua terdiri atas individu 6, 7, 9, 10, 11, dan 12 (Tabel 2).

\section{Jarak Genetik Intra dan Inter Spesies}

Berdasarkan perbedaan rata-rata jarak genetik gen COI dengan model kimura 2parameter menghasilkan intra individu populasi Sukabumi sebesar 0,001 atau $0,1 \%$ dan populasi Sentul sebesar 0,001 atau 0,1\%. Rata-rata jarak genetik antar populasi Sukabumi dan Sentul sebesar 0,192 atau $19,2 \%$. Perbedaan rata-rata jarak genetik populasi Sukabumi dan spesies Chaerephon plicatus (KY581660.1) sebesar 0,031 atau $3,1 \%$ dan populasi Sentul dengan spesies Hipposideros larvatus (HM540393.1) sebesar 0,052 atau 5,2\% (Tabel 3). 


\section{PEMBAHASAN}

Amplifikasi gen COI menggunakan primer spesifik dengan panjang sekuen $650 \mathrm{bp}$. Hasil ekstraksi DNA total, setelah dilakukan elektroforesis menunjukkan pita jelas dan terang. Hal ini karena konsentrasi DNA yang cukup tinggi. Faktor yang memengaruhi keberhasilan amplifikasi gen COI adalah kemurnian DNA hasil purifikasi (Sentausa, 2003). Komposisi bahan pereaksi, serta kondisi PCR yang tepat, terutama pada proses penempelan primer pada tahap annealing. Tahap annealing memungkinkan primer forward dan reverse akan menempel secara spesifik pada kedua ujung DNA cetakan sehingga dibutuhkan optimasi suhu pada tahap ini. Suhu optimum penempelan primer pada saat amplifikasi sampel yaitu $59{ }^{\circ} \mathrm{C}$. Jika suhu penempelan primer terlalu tinggi dari suhu optimum, menyebabkan primer tidak menempel pada DNA cetakan. Jika suhu penempelan primer terlalu rendah dari suhu penempelan optimum menyebabkan mispriming, yaitu penempelan primer pada tempat yang salah pada DNA cetakan sehingga dihasilkan produk non spesifik. Oleh karena itu, dilakukan optimasi terhadap suhu penempelan primer (Newton \& Graham, 1997).

Penyejajaran 23 sampel sekuen DNA menunjukkan bahwa terdapat situs variabel sebesar 28,91\%, dan situs konserve/lestari sebesar 71,08\% berdasarkan gen COI parsial. Berdasarkan posisi basa nukleotida yang polimorfik dari lokasi Sukabumi hanya terdapat satu situs basa nukleotida yang berbeda yaitu pada situs 267 dan lokasi Sentul hanya terdapat satu situs basa nukleotida yang berbeda, yaitu pada situs 471. Gen COI biasanya digunakan sebagai "DNA Barcode" karena memiliki komposisi nukleotida yang sedikit variasi, sehingga gen ini hanya digunakan untuk identifikasi spesies pada berbagai taksa (Solihin, 1994; Hebert et al., 2003).

Identifikasi spesies kelelawar dilakukan dengan melihat tingkat kemiripan (\%) sekuen gen COI antara jenis yang didapat dan jenis kelelawar yang tersedia di GenBank. Sampel yang berasal dari Sukabumi merupakan spesies Chaerephon plicatus dengan nilai Query-cover sebesar $98 \%$ dan nilai identity 97,08\%. Sampel yang berasal dari Sentul berdasarkan hasil
BLASTn lebih dekat dengan Hipposideros larvatus dengan nilai Query-cover sebesar 97\% dan nilai identity 94,85\% (Tabel 1). Berdasarkan nilai identity gen COI diketahui bahwa sampel dari Sentul memiliki nilai perbedaan sebesar $>3 \%$. Menurut Hebert et al. (2003) jika identitas genetik spesies tersebut memiliki perbedaan sebesar $>3 \%$ maka spesies tersebut adalah spesies yang berbeda. Peneliti lain, yaitu Tobe, Kitchener, dan Linacre (2010) memberikan kisaran yang lebih rendah lagi yaitu antara 0,015-0,025 terutama untuk spesies mamalia. Oleh karena itu spesies kelelawar yang ditemukan di Sentul ada kemungkinan merupakan "spesies berbeda". Namun demikian ketidaktersediaan data di GenBank belum dapat ditentukan jenis spesiesnya baru dapat di tentukan kedekatannya. Apabila sudah dapat ditentukan spesiesnya secara definitif maka akan dicatatkan di GenBank dengan kode akses tertentu dan dapat dijadikan standar spesies yang ada di Indonesia.

Hasil analisis haplotipe instraspesies pada populasi Sukabumi dan Sentul menunjukkan masing-masing dua haplotipe berbeda. Variasi yang terjadi pada basa nukleotida disebabkan oleh adanya mutasi. Mutasi menjadi penyebab utama perbedaan variasi basa nukleotida pada gen COI. Variasi yang kecil dapat memengaruhi keidentikan suatu spesies dan bahkan dapat memengaruhi susunan asam amino yang mengkodekan protein (Cracraft \& Helm-Bychowski, 1991).

Jarak genetik populasi Sentul dengan hasil BLASTn diduga spesies Hipposideros larvatus memiliki perbedaan secara genetik. Menurut Hebert et al. (2003) jika identitas genetik spesies tersebut menunjukkan perbedaan di atas 3\% maka spesies tersebut adalah spesies yang berbeda. Kelompok populasi tersebut masih berasal dari origin spesies yang sama. Gen-gen yang berasal dari nenek moyang (ancestors) masih tetap diturunkan. Semakin besar nilai jarak genetik (p-distance) di antara suatu populasi atau individu, semakin terisolasi antara satu dengan lainnya. Jarak genetik menunjukkan kemungkinan adanya pengaruh isolasi geografis terhadap suatu populasi (Ingman, Kaessmann, Pääbo, \& Gyllensten, 2000). Kisaran nilai jarak genetik untuk membedakan 
intrerspesies pada mamalia menurut Tobe et al. (2010) yaitu antara 0,015-0,025.

\section{SIMPULAN DAN SARAN}

Identifikasi secara genetik dengan menggunakan gen COI menunjukkan bahwa kelelawar yang berasal dari Gua Lalay Sukabumi adalah spesies Chaerephon plicatus dengan jarak genetik sebesar 3,1\%. Kelelawar yang berasal dari Gua Agung Garunggang memiliki kedekatan dengan spesies Hipposideros larvatus namun memiliki jarak genetik sebesar 5,2\%.

\section{UCAPAN TERIMA KASIH}

Terima kasih kepada Perusahaan Umum Daerah Pesona Pariwisata Kabupaten Sukabumi dan BKPH Bogor KPH Bogor RPH Babakan Madang Perum Perhutani Divisi Regional Jawa Barat yang telah memberikan perizinan penelitian dan pengambilan sampel di Gua Lalay Palabuhan Ratu Sukabumi dan Gua Agung Garunggang Sentul.

\section{REFERENSI}

Aguirre, L., Lens, L., \& Matthysen, E. (2003). Pattern of roost use by bats in a neotropical savanna: Implications for conservation. Biological Conservation, 11(3), 435-443. doi: 10.1016/S00063207(02)00313-0.

Hebert, P. D. N., Ratnasingham, S., \& De Waard, J. R. (2003). Barcoding animal life: Cytochrome c oxidase subunit 1 divergences among closely related species. Proceedings of The Royal Society B: Biological Sciences, 270, 96-99. doi: 10.1098/rsbl.2003.0025.

Cracraft, J., \& Helm-Bychowski, K. (1991). Parsimony and phylogenetic inference using DNA sequences: Some methodological strategies. in phylogenetic analysis of DNA sequences. New York: Oxford University Press.

Ingman, M., Kaessmann, H., Pääbo, S., \& Gyllensten, U. (2000). Mitochondrial genome variation and the origin of modern humans. Nature: National Academic Journal of Architecture, 408(6813), 708-713. doi: $10.1038 / 35047064$.
Kumar, S., Stecher, G., \& Tamura, K. (2016). MEGA7: Molecular evolutionary genetics analysis version 7.0 for bigger datasets. Molecular Biology and Evolution, 33(7), 1870-1874.

Newton, C. R., \& Graham, A. (1997). PCR introduction to biotechnique second edition. Oxford (GB): Bios Scientific Publisher Ltd.

Nowak, R. M. (1999). Walker's mammals of the world, vol.1. Baltimore and London: John Hopkins University Press.

Qiagen. (2003). QIAamp DNA mini kit and DNA blood mini kit handbook. Germany: Qiagen pr.

Seckerdieck, A., Walther, B., \& Halle, S. (2005). Alternative use of two different roost types by a maternity colony of the lesser horseshoe bat (Rhinolophus hipposideros). Mammalian BiologyZeitschrift für Säugetierkunde, 70(4), 201-209. doi: 10.1016/j.mambio.2004.10.002.

Sentausa, E. (2003). Studi DNA prasejarah dari tulang manusia Situs Arkeologi Tadulako, Sulawesi Tengah (Skripsi sarjana). Fakultas Matematika dan Ilmu Pengetahuan Alam, Institut Pertanian Bogor, Bogor, Indonesia.

Solihin, D. D. (1994). Peran DNA mitokondria (mtDNA) dalam studi keragaman genetik dan biologi populasi pada hewan. Hayati, 1(1), 1-4.

Suyanto, A. (2001). Kelelawar di Indonesia seri panduan lapangan. Bogor: Pusat Penelitian dan Pengembangan BiologiLIPI.

Tobe, S. S., Kitchener, A. C., \& Linacre, A. M. T. (2010). Reconstruction mammalian phylogenies: A detailed comparison of the cythochrome $b$ and cythochrome oxidase subunit $i$ mitochondrial genes. PLOS One, 5(11), e14156.

Wijayanti, F. (2011). Ekologi, relung pakan, dan strategi adaptasi kelelawar penghuni gua di Karst Gombong Kebumen Jawa Tengah (Disertasi doktoral). Program Studi Mayor Biosains Hewan, Fakultas Matematika dan Ilmu Pengetahuan Alam, Institut Pertanian Bogor, Bogor, Indonesia. 
Willis, C. K. R., \& Brigham, M. (2004). Roost switching, roost sharing and social cohesion: Forest-dwelling big brown bats, Eptesicus fuscus, conform to the fission-fusion model. Animal Behaviour, 68, 495-505. doi: 10.1016/j.anbehav.2004.12.002. 